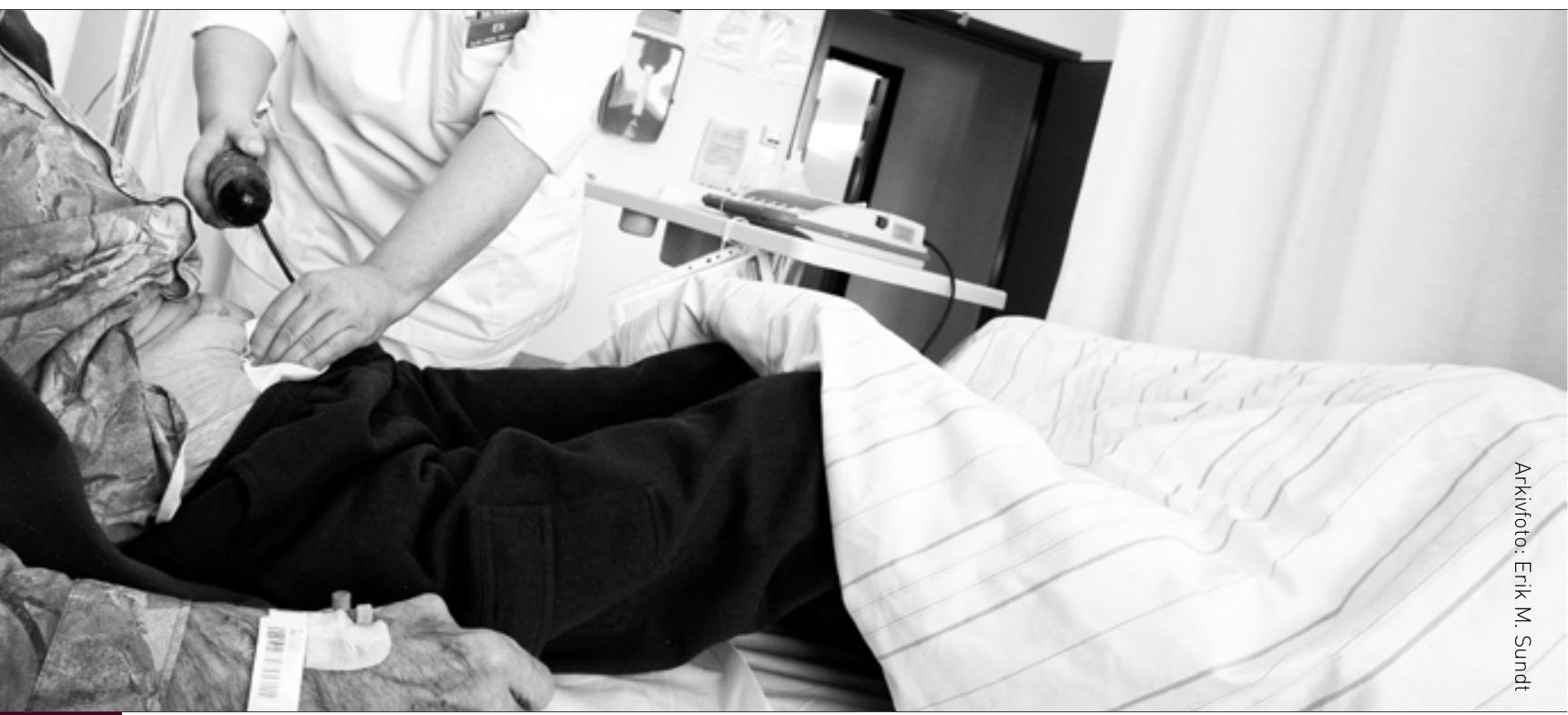

Bakgrunn: Blæredysfunksjon er hyppig ved multippel sklerose (MS). Det kan være et debutsymptom på MS, eller oppstå senere i sykdomsforløpet.

Hensikt: Hensikten med studien var å kartlegge forekomst og type symptomer på blæredysfunksjon hos personer som har hatt MS i lang tid, og å unders øke om deres funksjonsnivå hadde sammenheng med grad av blæredysfunksjon.

Metode: Et randomisert utvalg av en kohort på 175 personer med symptomdebut på MS mellom 1976 og 1986 ble invitert til å være med i studien, og
32 kvinner og 20 menn ble inkludert. Personenes funksjonsnivå ble registrert ved bruk av Expanded Disability Status Scale (EDSS). Symptomer på blæredysfunksjon ble registrert under samtale med uroterapeut, og ved selvrapporteringsskjemaet International Prostate Symptom Score (IPSS). Objektive unders $\varnothing$ kelser ble gjort ved hjelp av miksjonslister ført hjemme, og uroflowmetri- og resturinmålinger utført ved konsultasjon hos uroterapeut.

Resultat: Over halvparten av respondentene rapporterte symptomer på blæredysfunksjon. Det var stor grad av sammenheng mellom hva personene rapporterte selv, og hva som ble funnet ved objektive undersøkelser. Grad av blæredysfunksjon økte i samsvar med personenes reduserte funksjonsnivå, men mange av de med et godt funksjonsnivå hadde også symptomer på blæredysfunksjon.

Konklusjon: Funnene i studien viser at det er grunn til å ha fokus på kartlegging av symptomer på blæredysfunksjon hos personer med MS, uavhengig av deres funksjonsnivå. Enkel utredning kan gi nyttig informasjon om forekomst av blæredysfunksjon hos denne pasientgruppen.

\section{Bladder dysfunction in people with multiple sclerosis}

Background: Bladder dysfunction is frequent in multiple sclerosis (MS) sufferers, and may be present at onset, or occur later during the course of the disease.

Objectives: The objective of this study was to record the incidence and type of bladder dysfunction in people who have had MS for a long time, and investigate whether their disability level was related to a degree of urinary problems.

Method: A randomized sample from a group consisting of 175 persons with onset of symptoms between 1976 and
1986 was invited to participate in the study, and 32 women and 20 were ultimately included. The person's disability level was recorded using the Expanded Disability Status Scale (EDSS). Their symptoms regarding bladder dysfunction were recorded by conversations with the urotherapist, and by a self-reporting form, the International Prostate Symptom Score (IPSS). The objective measurements were conducted using frequencyvolume-charts (FVC), and by uroflowmetri and post-void-residual (PVR) measurement, carried out through a consultation with the urotherapist.

Results: More than half of the respondents reported symptoms of bladder dysfunction. There was a high degree of correspondence between selfreported symptoms and objective findings. The degree of bladder dysfunction increased relative to the person's reduced functioning, however, many of those that were well functioning also had symptoms.

Conclusion: The findings in this study underline the importance of evaluating bladder dysfunction in people with MS, regardless of the person's disability level. Simple measurements can provide useful information about bladder dysfunction in these patients.

Keywords: Neurology, urinary tract, bladder dysfunction, incontinence, multiple sclerosis, questionnaire. 


\section{"Blæeredysfunksjon hos personer med multippel sklerose}

Forfattere: Jannicke Frugård, Berit Rokne, Anne Britt Rundhovde Skår, Monica W. Nortvedt

\author{
NøKKELORD \\ - Nevrologi \\ - Urinveier \\ - Inkontinens \\ - Kronisk sykdom \\ - Spørreskjema.
}

\section{INTRODUKSJON}

Multippel sklerose (MS), er en kronisk immunmediert sykdom i sentralnervesystemet som skader myelinet rundt nervetrådene slik at impulsledningen forstyrres. Sykdommen kan medføre forskjellige symptomer, som lammelser, syns- og sensibilitetsforstyrrelser, spasmer og tremor, fatigue, smerter, kognitiv svikt, samt blære-, tarm- og seksualproblemer (1). Det er stor forskningsaktivitet både nasjonalt og internasjonalt for å generere kunnskap om årsakssammenhenger til sykdommen, type og grad av symptomer, samt for å utvikle nye behandlingsmetoder for personer med MS. Likevel er det fortsatt et stort behov for kunnskap om hvordan vi best kan hjelpe personer med MS til å leve med sin kroniske sykdom og håndtere de ulike symptomene sykdommen medfører (2-4).

Blæredysfunksjon er hyppig ved MS. Studier viser at 75-80 prosent vil få problemer med blærefunksjonen i løpet av sykdomsforløpet (5). De vanligste symptomene, som i litteraturen beskrives som Lower Urinary Tract Symptoms (LUTS), er hyppig vannlating (pollakisuri), uimotståelig sterk vannlatingstrang (urgency), ulike typer lekkasje (inkontinens), svak stråle, dårlig tømming (retensjon) $\mathrm{og}$ residiverende urinveisinfeksjoner (6). Symptomene kan være til stede ved sykdomsdebut, eller oppstå senere i sykdomsforløpet (7) og de kan endres underveis. Menn og kvinner kan ha ulik type blæredysfunksjon på grunn av anatomiske forskjeller, noe som også kan gi ulike symptomer (8). Mange av de som har symptomer på blæredysfunksjon har en høy grad av funksjonssvikt. Studier viser imidlertid at 50 prosent av de pasientene som ikke kan karakteriseres å ha funksjonssvikt, har symptomer på blæredysfunksjon etter ti til 20 års sykdom og derav redusert livskvalitet $(9,10)$. Det er bred enighet internasjonalt om at det er viktig å kartlegge blæredysfunksjon hos personer med MS (8). Det er imidlertid mangel på standardisert utredning av dette i Norge, og derfor behov for kunnskap om hvordan dette kan gjøres i praksis.

Hensikten med denne studien var å kartlegge forekomst og type blæredysfunksjon hos personer som har hatt MS i lang tid, med følgende problemstilling som utgangspunkt:

- Hvilke symptomer på blæredysfunksjon er de mest vanlige hos personer med MS?

- I hvilken grad er det samsvar mellom selvrapporterte symptomer registrert på spørreskjema

\section{Hva tilfører denne artikkelen?}

70-80 prosent av dem som lider av MS vil få problemer med blæredysfunksjon i løpet av sykdomsforløpet. Studien viser at problemene kan utredes på en enkel måte, som kan danne utgangspunkt for beslutninger om behandlingstiltak.

\section{Mer om forfatterne:}

Jannicke Frugård er sykepleier og uroterapeut med master i helsefag. Hun er ansatt ved Kirurgisk klinikk, urologisk avdeling, Haukeland universitetssykehus. Berit Rokne er professor ved Institutt for samfunnsmedisinske fag, Universitetet i Bergen og Haukeland universitetssykehus. Anne Britt Rundhovde Skår er spesialsykepleier med master i samfunnsarbeid. Hun er ansatt ved Nasjonalt kompetansesenter for MS og Nevrologisk avdeling, Haukeland universitetssykehus. Monica W. Nortvedt er professor ved Høgskolen i Bergen, Avdeling for Helse- og sosialfag. Kontaktperson: jannicke.frugårda helsebergen.no 
og i samtale med uroterapeut, og funn gjort ved objektive undersøkelser?

- Er det forskjell mellom menn og kvinner når det gjelder selvrapporterte symptomer registrert på spørreskjema og i samtale med uroterapeut, og funn gjort ved objektive undersøkelser?

- Er det sammenheng mellom funksjonsnivå, selvrapporterte symptomer og funn gjort ved objektive undersøkelser?

\section{METODE Utvalg}

Alle personer med MS i Hordaland, med symptomdebut mellom 1976-1986, er med i en kohortstudie ved Nasjonalt kompetansesenter for MS, Nevrologisk avdeling, Haukeland universitetssykehus. Pasientene er fulgt opp siden 1988 med regelmessig kartlegging av blant annet funksjonsnivå, livskvalitet og ulike symptomer som følge av MS. Kohorten besto i 2003 av 175 personer, med sykdomsvarighet på 20-30 år. Utvalget for denne delstudien, som hadde fokus på blærefunksjon, var et randomisert utvalg av denne kohorten. Av kapasitetshensyn ble cirka halvparten $(\mathrm{n}=85)$ randomisert til urologisk konsultasjon og fikk tilbud om strukturert kartlegging av blærefunksjon hos uroterapeut, mens resten, ved behov, skulle få samme tilbudet kom i gruppen som fikk det aktuelle tilbudet (11). Inklusjonskriterier, i tillegg til å være en del av MS-kohorten, var at deltakerne kunne svare på spørreskjemaet, eventuelt med skriveteknisk hjelp, og være fysisk i stand til å komme til urologisk poliklinikk. Av de 85 personene som fikk tilbud om å delta, var det 55 personer som møtte til konsultasjon. Av dem som ikke møtte, hadde fem for dårlig funksjonsnivå, fire personer var flyttet, to var døde, og 19 personer ønsket ikke å delta. Tre av de 55 ble ekskludert fra analysen fordi de manglet samtykkeerklæring og data fra nevrologisk avdeling. Datainnsamling ble gjort i 2003 og 2004.

\section{Metoder for datainnsamling}

Det ble samlet data for å kartlegge symptomer og funn på blæredysfunksjon. I tillegg ble personenes funksjonsnivå registrert ved bruk av Kurtzkes Expanded Disability Status Scale (EDSS) (12), type MS, samt årstall for symptomdebut og diagnose.

1. Kartlegging av funksjonsnivå med Expanded Disability Status Scale-EDSS

EDSS baseres på nevrologisk undersøkelse hvor man skårer pasientens grad av funksjonssvikt som følge av MS (12). EDSS angis fra $0-10$ der 0 er normal

\section{Over halvparten av respondentene i denne studien rapporterte vannlatingssymptomer i storre eller mindre grad.}

senere. Randomisering ble gjort ved hjelp av et computerprogram som foretok «random assignment» ved at alle i kohorten tilfeldig fikk nummeret 0 eller 1 (50/50), og der de med nummer 1 funksjon og 10 er død på grunn av MS. Ved EDSS skår på $<4,0$ har personen ubegrenset gangdistanse, mens han eller hun ved en skår på 6,0 er avhengig av hjelpemidler for å gå 100 meter.
EDSS sier ikke noe om personens opplevelse av sykdom.

\section{Kartlegging av subjektive symp- tomer på blaredysfunksjon}

a) International Prostate Symptom Score - IPSS: IPSS ble opprinnelig utviklet for å kartlegge subjektive symptomer på blæredysfunksjon hos menn med benign prostatahyperplasi (13). Imidlertid har det vist seg at I-PSS er godt egnet for å kartlegge LUTS både hos kvinner og menn (14). Det er et internasjonalt anerkjent spørreskjema, enkelt å fylle ut, og er mye brukt i studier som kartlegger forekomst av slike symptomer hos begge kjønn, også hos personer med MS (15, 16). Skjemaet er oversatt til norsk og godkjent ved konsensus i Norsk urologisk forening. Det er brukt i flere nasjonale studier (17). Skjemaet inneholder syv spørsmål relatert til lagrings-, tømmings- og posttømmingssymptomer: 1: følelse av dårlig blæretømming, 2: pollakisuri, 3: porsjonsvis vannlating, 4: urgency, 5: svak urinstråle, 6: trykke eller presse for å starte vannlating, 7: nocturi. Grad av symptomer kan angis med seks alternativer på en Likertskala fra $0-5$, der aldri er 0 og nesten alltid er 5. Svarene regnes sammen til en sumskår $0-35$, der skår mellom 0 og 7 regnes som ingen eller milde symptomer, 8-19 som moderate symptomer, og 20-35 som alvorlige symptomer (14). Skjemaet inneholder i tillegg et globalt spørsmål om hvordan livskvalitet (QOL) påvirkes av vannlatingssymptomene på en skala fra 0-6, der 0 er meget godt fornøyd, og 6 er har det forferdelig. I-PSS skjemaet inneholder ikke spørsmål om urinlekkasje og urinveisinfeksjon, noe som forekommer ofte hos personer med MS (6). Skjemaet ble derfor 
supplert med et ja/nei spørsmål om urinlekkasje, og et spørsmål om urinveisinfeksjon med fire alternative svar på en skala fra nei til mer enn fem ganger i løpet av de siste seks måneder.

b) Miksjonsanamnese: Ved konsultasjon hos uroterapeut fikk pasientene med egne ord angi hvilke vannlatingssymptomer de hadde. Denne anamnesen ble $\mathrm{i}$ studien nedtegnet $\mathrm{i}$ pasientens journal, og det ble gjort en retrospektiv gjennomgang av disse journalnotatene, der utsagn om hvorvidt de hadde symptomer på blæredysfunksjon generelt, ble klassifisert på en skala fra $0-2$, $\operatorname{der} 0=$ ingen symptomer, $1=$ =periodevis symptomer og 2= alltid symptomer. Spesifikke vannlatingssymptomer ble også klassifisert på en skala fra $0-2$, der $0=$ ikke angitt å ha aktuelle symptomer, 1 = aktuelle symptomer i perioder og $2=$ aktuelle symptomer hele tiden. Retrospektiv gjennomgang av journalnotater var av interesse for å finne ut om IPSS kan brukes som et screeninginstrument for å finne symptomer på blæredysfunksjon, før pasienten eventuelt henvises til videre kartlegging.

\section{Objektiv kartlegging av bloe- redysfunksjon}

a) Miksjonslister: Pasientene fikk instruksjon i å føre miksjonslister hjemme i to døgn, med registrering av klokkeslett for hver vannlating både dag $\mathrm{og}$ natt, samt måle hvert volum. En slik registrering gir opplysninger om døgnvolum, gjennomsnittlig enkeltvolum, samt minste og største volum. Den gir i tillegg opplysninger om vannlatingsmønster både på dagtid og om natten, og er et viktig instrument i utredning av LUTS (18).

b) Uroflowmetri /resturinmåling: Uroflowmetri (flow) gjøres ved at pasienten later vannet på et spesialtoalett som måler mengde urin, kraften på urinstrålen, målt i ml per sekund, der maksimal kraft beskrives som Q-max, og gjennomsnittlig kraft som Q-ave. Tiden vannlating tar registreres også (i sekund) (19). Flow ble i studien gjort ved hjelp av URODYN 1000 (Dantec, Scovlunde, Danmark). For å vurdere hvor godt blæren var tømt, ble resturin målt ved ultralyd med Leopard 2001 (Brüel og Kjær Medical, Danmark).

\section{Etiske aspekter}

Studien er et samarbeidsprosjekt mellom nevrologisk- og urologisk avdeling, Haukeland Universitetssykehus, godkjent av Regional komité for medisinsk og helsefaglig forskningsetikk (REK) og Norsk samfunnsvitenskapelig datatjeneste (NSD), Skriftlig samtykke ble innhentet ved nevrologisk avdeling som ledd i den aktuelle studien de deltok i på dette tidspunktet.

\section{Datainnsamling}

Datainnsamling ved nevrologisk avdeling: IPSS-skjema ble sendt ut sammen med andre skjemaer respondentene skulle fylle ut i forbindelse med kohortstudien. Skjemaene ble sendt med påført løpenummer, og frankert returkonvolutt. Personene som ble randomisert til urologisk konsultasjon, fikk muntlig informasjon om hensikten med studien av MS-sykepleier og data om type MS, funksjonsnivå, samt årstall for symptomdebut og diagnose, ble registrert ved Nevrologisk avdeling.

Datainnsamling ved urologisk poliklinikk: Deltakerne fikk skriftlig informasjon om studien ved innkalling til konsultasjon, og ny muntlig gjennomgang ved første besøk. Konsultasjonen besto av to besøk hos uroterapeut for kartlegging og iverksetting av eventuelle behandlingstiltak. Ved første besøk ble det gjort strukturert miksjonsanamnese. Etter cirka 14 dager kom pasienten tilbake til ny konsultasjon med utfylte miksjonslister. For dem som var i stand til det, ble det gjort flow to ganger med påfølgende måling av resturin.

\section{Statistiske analyser}

For analyse av data er det brukt SPSS (Statistical Package for Social Science), versjon 15 (SPSS Inc. Chicago, IL, USA). Det er gjort en deskriptiv analyse av innsamlete data for utvalget. For dem som hadde to flowundersøkelser, ble den med størst miksjonsvolum og påfølgende resturinmåling brukt i analysen. For å teste forskjell i resultater for menn og kvinner er det, avhengig av dataenes målenivå, brukt t-test og kji-kvadrattest med signifikansnivå $\mathrm{p} \leq 0,05$. En mulig samvariasjon mellom IPSS-skjema, funn i miksjonsanamnesen, og objektive undersøkelser, er testet ved hjelp av Pearsons korrelasjonskoefissient - $r$ (tosidig). For å undersøke om funksjonsnivå målt ved EDSS påvirker sammenheng mellom sumskår i IPSS og livskvalitetsindeks, er det brukt lineær regresjonsanalyse med livskvalitetsindeks som avhengig variabel og EDSS og sumskår i IPSS som uavhengige variabler.

\section{RESULTATER}

Utvalget besto av 52 personer hvorav 20 menn og 32 kvinner med gjennomsnittsalder 52,1 år $( \pm 8,3)$. For utfyllende oversikt over demografiske og kliniske variabler, se tabell 1.

Symptomer målt ved IPSS: Symptomene som forekom hyppigst var tømningsvansker, hyp- 
pig vannlating, uimotståelig sterk vannlatingstrang, svak urinstråle og nocturi, se tabell 2.

Sammenheng mellom miksjonsanamnese og symptomer målt ved IPSS: På spørsmål i miksjonsanamnesen om vannlatingssymptomer generelt, anga 30 (57,7 prosent) av respondentene at de alltid hadde symptomer, mens 13 (25 prosent) anga å ha symptomer i perioder. Kvinnene var mer plaget av anstrengelseslekkasje enn menn $(\mathrm{p}=0,01)$, mens menn var mer plaget av svak stråle enn kvinnene $(\mathrm{p}=0,02)$. Spesifikke vannlatingssymptomer angitt ved strukturert miksjonsanamnese var mindre uttalte enn det de rapporterte på IPSS, men det var signifikant samsvar når det gjaldt pollakisuri, urgency og svak urinstråle. Det samme gjaldt tilleggsspørsmål vedrørende urinveisinfeksjon og urinlekkasje.

Sammenheng mellom symptomer og funn: Førtito personer hadde fylt ut miksjonslister i to døgn (tabell 3). Gjennomsnittlig minste enkeltvolum var mindre hos kvinner enn hos menn (henholdsvis 86 og $141 \mathrm{ml}$ ), ellers var det ingen kjønnsforskjeller. Funn i miksjonslister samsvarte med hva respondentene anga som symptomer på IPSS om pollakisuri $(r=0,70, p<0,01)$ og nocturi $(r=0,33, p<0,05)$. Førtifire personer gjennomførte 1-2 uroflowmetrier med påfølgende resturinmåling (tabell 4). Q-max korrelerte negativt med I-PSS om svak stråle $(r=-0,47$, $\mathrm{p}<0,01$ ) (jo høyere IPSS skår, jo svakere stråle). Mennene hadde svakere stråle og lengre flowtid enn kvinnene. Gjennomsnittlig resturinmengde for kvinner var $76 \mathrm{ml}$, og for menn 106 ml. I-PSS-spørsmål om følelse av dårlig tømming, korrelerte signifikant med målt resturin $(\mathrm{r}=0,36, \mathrm{p}<0,05)$. Det ble ikke funnet tilsvarende sammenheng mellom det de hadde angitt $\mathrm{i}$ miksjonsanamnesen og objektive funn, se tabell 4 .

Sammenheng mellom personenes funksjonsnivå, symptomer og livskvalitetsindeks (QOL) målt ved IPSS: Personene med redusert funksjonsnivå rapporterte høyere symptombelastning på IPSS og lavere livskvalitet. Redusert livskvalitet var mest relatert til

TABELL 1: Beskrivelse av utvalget, demografiske og kliniske variabler.

\begin{tabular}{|c|c|c|c|}
\hline & Hele utvalget & Menn & Kvinner \\
\hline Kjønn n (\%) & $52(100)$ & $20(38,5)$ & $32(61,5)$ \\
\hline Alder, gjennomsnitt ( \pm SD) & $52,1(8,3)$ & $52,8(8,4) 55$ & $51,8(8,4$ \\
\hline $\begin{array}{l}\text { Antall år siden symptomdebut, } \\
\text { gjennomsnitt }( \pm S D)\end{array}$ & $22(3,1)$ & $21(2,8)$ & $22(3,2)$ \\
\hline $\begin{array}{l}\text { Type MS n (\%): } \\
\text {-Relapsing remittent-RR }\end{array}$ & $38(73,1)$ & $12(60,0)$ & $26(81,3)$ \\
\hline -Primær progressiv - PP & $6(11,5)$ & $3(15,0)$ & $3(9,4)$ \\
\hline -Sekundær progressive - SP & $8(15,4)$ & $5(25,0)$ & $3(9,4)$ \\
\hline $\begin{array}{l}\text { Antall år siden diagnose } \\
\text { gjennomsnitt }( \pm S D)\end{array}$ & $16(5,2)$ & $17(4,1)$ & $15(5,8)$ \\
\hline $\begin{array}{l}\text { Funksjonsnivå, målt ved EDSS, } \\
\text { gjennomsnitt }( \pm S D) \text { range } 1-8\end{array}$ & $4,2(2,0)$ & $4,8(2,2)$ & $3,9(1,8)$ \\
\hline
\end{tabular}

vannlatingssymptomer og i mindre grad påvirket av funksjonsnivå, se tabell 5 .

\section{DISKUSJON}

Over halvparten av respondentene i denne studien rapporterte vannlatingssymptomer i større eller mindre grad. Det var varierende grad av samsvar mellom symptomer angitt på I-PSS skjema og det de anga i miksjonsanamnesen, mens det var signifikant sammenheng mellom symptomer registrert på IPSS, funn i miksjonslister og flow-/resturinmålinger når det gjaldt pollakisuri, nocturi, svak urinstråle og følelse av dårlig tømming. Personenes grad av symptomer på blæredysfunksjon økte med redusert funksjonsnivå, men også de med et godt funksjonsnivå hadde symptomer. Funksjonsnivå hadde mindre innvirkning på livskvalitetsindeks (QOL) i IPSS enn vannlatingssymptomer.

Samsvar mellom IPSS og miksjonsanamnese: Varierende grad av samsvar mellom symptomskår registrert på IPSS og det respondentene anga som plagsomme symptomer i miksjonsanamnesen, kan ha ulike forklaringer. IPSS-skjemaet ble fylt ut hjemme som et av flere spørreskjema i studien de deltok i. Det er mulig at det er lettere å uttrykke sine symptomer når de er konkretisert enkeltvis på et skjema. Ved miksjonsanamnese, ber man pasienten om å fortelle med egne ord hva som er de mest plagsomme vannlatingssymptomene, noe som kan føre til at han eller hun ikke nevner symptomer som ikke er spesielt plagsomme. I denne studien var det gjort retrospektiv gjennomgang av uroterapeutens notat i journalen. Studier har vist at det som nedtegnes i journalen kan være mangelfullt, 
TABELL 2: Vannlatingsproblemer hos menn og kvinner registrert ved I-PSS og tilleggsspørsmål om urinlekkasje og urinveisinfeksjoner.

\begin{tabular}{|c|c|c|c|c|}
\hline & Aldri n (\%) & $\begin{array}{l}\text { Mindre enn halvpar- } \\
\text { ten av gangene } \mathrm{n}(\%)\end{array}$ & $\begin{array}{l}\text { Mer enn halvparten } \\
\text { av gangene (n }(\%)\end{array}$ & P-verdi \\
\hline \multicolumn{5}{|l|}{ Følelse av dårlig blæretømming $\mathrm{n}=50$} \\
\hline -menn & $3(15,8)$ & $8(42,1)$ & $8(42,1)$ & \\
\hline -kvinner & $6(19,4)$ & $13(41,9)$ & $12(38,7)$ & 0,780 \\
\hline \multicolumn{5}{|l|}{$\begin{array}{l}\text { Mindre enn to timer mellom hver } \\
\text { vannlating } n=49\end{array}$} \\
\hline -menn & $3(16,7)$ & $7(38,9)$ & $8(44,4)$ & \\
\hline -kvinner & $0(0)$ & $16(51,6)$ & $15(48,4)$ & 0,267 \\
\hline \multicolumn{5}{|l|}{ Porsjonsvis vannlating $n=50$} \\
\hline -menn & $5(26,3)$ & $5(26,3)$ & $9(47,4)$ & \\
\hline -kvinner & $12(38,7)$ & $13(41,9)$ & $6(19,4)$ & 0,158 \\
\hline \multicolumn{5}{|l|}{ Urgency $n=50$} \\
\hline -menn & $3(15,8)$ & $7(36,8)$ & $9(47,4)$ & \\
\hline -kvinner & $4(12,9)$ & $17(54,8)$ & $10(32,3)$ & 0,810 \\
\hline \multicolumn{5}{|l|}{ Svak urinstråle $n=49$} \\
\hline -menn & $1(5,6)$ & $5(27,8)$ & $12(66,7)$ & \\
\hline -kvinner & $8(25,8)$ & $16(51,6)$ & $7(22,6)$ & 0,013 \\
\hline \multicolumn{5}{|l|}{$\begin{array}{l}\text { Må trykke eller presse for å starte } \\
\text { vannlating } n=49\end{array}$} \\
\hline -menn & $4(22,2)$ & $7(38,9)$ & $7(38,9)$ & \\
\hline -kvinner & $12(38,7)$ & $11(35,5)$ & $8(25,8)$ & 0,249 \\
\hline Nocturi $n=47$ & Aldri & 1-2 ganger & 3 ganger eller mer & \\
\hline -menn & $4(23,5)$ & $10(58,8)$ & $3(17,6)$ & \\
\hline -kvinner & $10(33,3)$ & $13(43,3)$ & $7(23,3)$ & 0,837 \\
\hline \multirow[t]{2}{*}{ Total I-PSS score $n=48$} & $\begin{array}{l}\text { Ingen eller milde } \\
\text { symptomer }\end{array}$ & $\begin{array}{l}\text { Moderate } \\
\text { symptomer }\end{array}$ & $\begin{array}{l}\text { Alvorlige } \\
\text { symptomer }\end{array}$ & \\
\hline & $(0-7)$ & $(8-19)$ & $(20-35)$ & \\
\hline -menn & $3(16,7)$ & $7(38,9)$ & $8(44,4)$ & \\
\hline -kvinner & $9(30,0)$ & $17(56,7)$ & $4(13,3)$ & 0,378 \\
\hline Global livskvalitetsindeks (QoL) $n=51$ & Fornøyd & Blandede følelser & Misfornøyd & \\
\hline -menn & $10(50,0)$ & $3(15,0)$ & $7(35,0)$ & \\
\hline -kvinner & $23(74,2)$ & $5(16,1)$ & $3(9,7)$ & 0,079 \\
\hline $\begin{array}{l}\text { Inkontinens i løpet av de siste } 6 \mathrm{mnd} \\
\mathrm{n}=50\end{array}$ & Nei n (\%) & Ja n $(\%)$ & & \\
\hline -menn & $10(52,6)$ & $9(47,4)$ & & \\
\hline -kvinner & $9(29,0)$ & $22(71,0)$ & & 0,095 \\
\hline UVI i løpet av de siste $6 \mathrm{mnd} n=50$ & Nei & 1-2 ganger & 3 ganger eller mer & \\
\hline menn & $13(65,0)$ & $6(30,0)$ & $1(5,0)$ & \\
\hline -kvinner & $15(50,0)$ & $10(33,3)$ & $5(16,6)$ & 0,652 \\
\hline
\end{tabular}

og ikke alltid samsvarer med det som blir sagt om pasientens tilstand $\mathrm{i}$ intervju med sykepleier eller pasient $(20,21)$. En annen mulig årsak er at noen synes det er vanskelig å snakke om denne type plager, noe som tidligere er vist $\mathrm{i}$ en studie av en gruppe kvinner med MS og urinlekkasje (22). Det kan også være at når de er kommet til en spesialavdeling, føler de seg trygge på at sympto- 
mene blir tatt på alvor, og dermed ikke trenger å spesifiseres. Personer med MS har mange ulike plager å håndtere i hverdagen (1), noe som kanskje fører til at de blir selektive i hvilke symptomer de framhever i møtet med helsepersonell. I studier som er gjort for å finne ut hvordan personer med MS mestrer sin sykdom, har det vist seg at mange er passive i forhold til symptomer sykdommen medfører, da de kanskje ikke har kunnskap om hvilke muligheter som finnes for å gjøre noe med disse $(3,23)$. Dette underbygges av at vannlatingssymptomer, som i litteraturen er angitt som de mest plagsomme, nemlig pollakisuri, urgency, infeksjon og lekkasje (24), viste signifikant korrelasjon mellom IPSS-skjema og det som var angitt i miksjonsanamnesen. Det at kvinner rapporterte mer anstrengelseslekkasje enn menn, kan forklares med at kvinner, uavhengig av sin MS, kan ha svekket bekkenbunn. Det er anbefalt at man er oppmerksom på dette ved utredning og behandling av vannlatingsplager hos kvinner med MS (8), da det har betydning for valg av behandling hos den enkelte.

Miksjonslister, flow-/resturinmålinger, og sammenheng med symptomer: De som fylte ut miksjonslister og gjennomførte flowundersøkelser hadde bedre funksjonsnivå enn de som ikke gjorde dette. Funn i miksjonslistene er sammenfallende med studier gjort i normalpopulasjon på menn og kvinner når det gjelder gjennomsnittsverdier (25). Imid-

TABELL 3: Registrering av vannlating ved hjelp av miksjonslister utført hjemme i to døgn ( $N=42,13$ menn og 29 kvinner).

\begin{tabular}{|c|c|c|c|c|}
\hline & Gjennomsnitt & Range & SD & P verdi \\
\hline \multicolumn{5}{|c|}{ Gjennomsnittlig enkeltvolum (ml) } \\
\hline -menn & 259 & $56-666$ & 142 & \\
\hline -kvinner & 231 & $100-500$ & 96 & 0,451 \\
\hline \multicolumn{5}{|c|}{ Minste enkeltvolum (ml) } \\
\hline -menn & 141 & $30-300$ & 69 & \\
\hline -kvinner & 86 & $20-250$ & 55 & $<0,01$ \\
\hline \multicolumn{5}{|c|}{ Største enkeltvolum (ml) } \\
\hline -menn & 434 & $130-1300$ & 288 & \\
\hline -kvinner & 482 & $200-1000$ & 200 & 0,534 \\
\hline \multicolumn{5}{|c|}{ Døgnvolum (ml) } \\
\hline -menn & 1609 & $448-3000$ & 684 & \\
\hline -kvinner & 1960 & $656-3853$ & 843 & 0,196 \\
\hline \multicolumn{5}{|c|}{ Gjennomsnittlig frekvens dag (n) } \\
\hline -menn & 6,5 & $3,6-13,4$ & 2,4 & \\
\hline -kvinner & 7,8 & $4,0-13,0$ & 2,6 & 0,570 \\
\hline \multicolumn{5}{|c|}{ Gjennomsnittlig frekvens natt (n) } \\
\hline -menn & 0,7 & $0-2,4$ & 0,8 & \\
\hline -kvinner & 0,6 & $0-1,5$ & 0,5 & 0,803 \\
\hline
\end{tabular}

lertid viser resultatene i denne studien en større spredning i verdiene både når det gjelder største og minste enkeltvolum, døgnvolum og miksjonsfrekvens per dag, enn det som er rapportert i normalpopulasjonen (ibid.). Dette kan ha sammenheng med variasjon av symptomer, ved at noen var plaget med pollakisuri og urgency, mens andre hadde nedsatt sensibilitet for blærefylling, og dermed høyere enkeltvolum og lavere miksjonsfrekvens. Det samme viste seg ved spredning i miksjonsvolum ved flow. En del av respondentene hadde store enkeltvolum både i miksjonslister og ved flow. Normalvariasjon i blærevolum er 250-500 ml, der man som regel anbefaler at blæren tømmes ved $400 \mathrm{ml}$ (26). Ved store blærevolum over lengre tid, kan blæremuskulaturen bli overstrukket, noe som kan gi dårligere kontraksjon under tømming, og derved økt fare for resturin, urinveisinfeksjon og lekkasje. Dette framheves også i litteratur som omhandler blæredysfunksjon hos personer med MS (27). I en studie fra 1980, utført på personer innlagt i sykehus med resturin og urinveisinfeksjoner som følge av MS, ble det gjort intervensjon med blæretrening med faste toalettider, og resturinmåling etter vannlating. Intervensjonen viste god effekt mens de var innlagt, men avtok en tid etter utreise, der de ikke hadde noen oppfølging (28). I en studie gjort på menn med LUTS, i form av pollakisuri, urgency og nocturi, ble miksjonslister brukt som utgangspunkt for miksjonsrådgivning. Dette hadde positiv effekt på vannlatingsmønsteret og reduserte plagene (29). Sammenliknet med resultater av flow- og resturinmålinger gjort på normalpopulasjon (30), hadde både menn og 
TABELL 4: Uroflowmetri (flow) og resturinmålinger, der flow med størst miksjonsvolum og påfølgende resturinmåling er brukt i analysen ( $N=44,14$ menn og 30 kvinner).

\begin{tabular}{|c|c|c|c|c|}
\hline & Gjennomsnitt & Range & SD & P-verdi \\
\hline \multicolumn{5}{|c|}{ Q-max ved flow (ml/s) } \\
\hline -menn & 12,2 & $6,3-25,7$ & 5,4 & \\
\hline -kvinner & 27,6 & $8,5-58,9$ & 12,3 & $<0,001$ \\
\hline \multicolumn{5}{|c|}{$Q$-ave ved flow $(\mathrm{ml} / \mathrm{s})$} \\
\hline -menn & 5,1 & $1,4-10,2$ & 2,7 & \\
\hline -kvinner & 14,1 & $3,5-37$ & 8,0 & $<0,001$ \\
\hline \multicolumn{5}{|c|}{ Flowtid (sek) } \\
\hline -menn & 91 & $39-318$ & 78 & \\
\hline -kvinner* & 40 & $15-128$ & 27 & 0,003 \\
\hline \multicolumn{5}{|c|}{ Miksjonsvolum flow (ml/s) } \\
\hline -menn & 307 & $107-657$ & 154 & \\
\hline -kvinner & 398 & $170-867$ & 179 & 0,110 \\
\hline \multicolumn{5}{|c|}{ Resturin etter flow (ml) } \\
\hline -menn & 106 & $41-211$ & 51 & \\
\hline -kvinner & 74 & $0-356$ & 76 & 0,162 \\
\hline
\end{tabular}

kvinner i denne studien svakere stråle og mer resturin. Mennene hadde svakere urinstråle enn kvinnene, noe som kan tyde på at de i tillegg til vannlatingssymptomer relatert til MS, også hadde obstruktive symptomer som følge av forstørret prostata. Dette er viktig å være oppmerksom på når det gjelder valg av behandling (8). Høy grad av samsvar mellom IPSS og objektive funn når det gjaldt miksjonsfrekvens dag, nocturi, følelse av dårlig tømming og svak stråle, samsvarer med funn i en nylig publisert artikkel fra Australia, som anbefaler IPSS som et screeninginstrument $i$ utredning av LUTS hos personer med MS (31).

Sammenheng mellom personenes funksjonsnivå og symptomer på bloredysfunksjon: Det er kjent at forekomst av blæredysfunksjon øker i samsvar med redusert funksjonsnivå, noe som også viste seg i denne studien. Det er likevel viktig å merke seg at de med et godt funksjonsnivå (EDSS skår < 4,0) også hadde symptomer på blæredysfunksjon, noe som tilsvarer funn rapportert i tidligere artikler $(10,32)$. Regresjonsanalyse viste

TABELL 5: Regresjonsanalyse med EDSS, I-PSS sumskår og livskvalitetsindex (QOL). QOL er avhengig variabel.

\begin{tabular}{lcc}
\hline $\mathrm{R}^{2}=\mathbf{0 , 4 7 9}$ & Betakoeffisient & P-verdi \\
EDSS- skår & $-0,043$ & 0,734 \\
I-PSS sumskår & 0,712 & $<0,001$ \\
\hline
\end{tabular}

at svaret de anga på spørsmålet om livskvalitet på IPSS i størst grad var knyttet til LUTS, og ikke til funksjonsnivå generelt. Dette indikerer at kartlegging av symptomer på blæredysfunksjon bør være uavhengig av personens funksjonsnivå.

\section{Styrker og begrensninger}

Denne studien var gjennomført hos et randomisert utvalg av en kohort, noe som gjør det mulig å generalisere funn til tilsvarende populasjon. Imidlertid var ikke alle respondentene med dårlig funksjonsnivå i stand til å svare på spørreskjema, fylle ut miksjonslister, eller gjennomføre flow- og resturinmålinger, noe som reduserer denne muligheten. Studien har gjort bruk av subjektive data med selvrapportering ved hjelp av et enkelt anerkjent spørreskjema, og objektive data ved bruk av miksjonslister og flow- og resturinmålinger. Ved å bruke et anerkjent spørreskjema som benyttes over hele verden, også i Norge, kan en lettere sammenlikne resultater med både nasjonal og internasjonal forskning. Retrospektiv gjennomgang av pasientjournal for å registrere miksjonsanamnese, kan være en usikker kilde til informasjon (21).

\section{KONKLUSJON}

Målet med utredning og behandling av vannlatingsproblemer hos personer med MS, er å bevare en normal nyrefunksjon ved å forebygge og behandle plagsomme symptomer som gir redusert livskvalitet (27). Funnene i denne studien viser at det er grunn til å ha fokus på kartlegging av blæredysfunksjon hos personer med MS, uavhengig av funksjonsnivå, og at enkel utredning kan gi nyttig informasjon om forekomst av blæredysfunksjon hos denne 
pasientgruppen. Spørreskjema, miksjonslister og resturinmålinger er enkle undersøkelser som kan iverksettes av helsepersonell, også utenfor spesialisthelsetjenesten. De kan danne beslutningsgrunnlag for hvorvidt henvisning til spesialist i urologi er nødvendig, eller om enkle

\section{REFERANSER}

1. Crayton HJ, Rossman H.S. Managing the symptoms of multiple sclerosis: a multimodal approach. Clin Ther, 2006;28:44560.

2. Metz LM, Patten SB, McGowan D. Symptomatic therapies of multiple sclerosis. Biomed Pharmacother, 1999:53:371-9.

3. Goretti B, Portaccio E, Zipoli V, Hakiki B, Siracusa G, Sorbi S, Amato MP. Coping strategies, psychological variables and their relationship with quality of life in multiple sclerosis. Neurol Sci, 2009; 30:15-20. 4. Lode K, Larsen JP, Bru E, Klevan G, Myhr KM, Nyland H. Patient information and coping styles in multiple sclerosis. Mult Scler, 2007; 13:792-9.

5. Woodward S. Current management of neurogenic bladder in patients with $\mathrm{MS}$. $\mathrm{Br}$ J Nurs, 2004;13:362-70.

6. DasGupta R, Fowler CJ. Sexual and urological dysfunction in multiple sclerosis: better understanding and improved therapies. Curr Opin Neurol, 2002; 15:271-8. 7. Giannantoni A, Scivoletto G, Di Stasi SM, Grasso MG, Finazzi Agró E, Collura G, Vespasiani G. Lower urinary tract dysfunction and disability status in patients with multiple sclerosis. Arch Phys Med Rehabil, 1999:80:437-41.

8. Fowler CJ, Panicker JN, Drake M, Harris C, Harrison SC, Kirby M, Lucas M, Macleod N, Mangnall J, North A, Porter B, Reid S, Russel N, Watkiss K, Welles M. A UK consensus on the management of the bladder in multiple sclerosis. Postgrad Med J, 2009; 85:552-9.

9. Nortvedt MW, Riise T, Myhr KM, Landtblom AM, Bakke A, Nyland H. Reduced quality of life among multiple sclerosis patients with sexual disturbance and bladder dysfunction. Mult Scler, 2001;7:231-5. 10. Nortvedt MW, Riise T, Frugård J, Mohn J, Bakke A, Skår AB, Nyland H, Glad SB, Myhr KM. Prevalence of bladder, bowel and sexual problems among multiple sclerosis patients two to five years after diagnosis. Mult Scler, 2007;13:106-12.

11. Polit DFD, Beck CTC. Nursing research. 2004.

12. Kurtzke JF. Rating neurologic impairment in multiple sclerosis: an expanded disability status scale (EDSS). Neurology, 1983:33:1444-52. behandlingstiltak kan initieres lokalt. Som måleinstrumenter for å vurdere effekt av eventuell behandling vil de også være nyttige.

Takk til leger og sykepleiere ved Nasjonalt kompetansesenter for MS, nevrologisk avdeling, Hau-

13. Barry MJ, Fowler FJ Jr, O>Leary MP, Bruskewitz RC, Holtgrewe HL, Mebust WK, Cockett AT. The American Urological Association symptom index for benign prostatic hyperplasia. The Measurement Committee of the American Urological Association. J Urol, 1992;148:1549-57.

14. Lepor H, Machi G. Comparison of AUA symptom index in unselected males and females between fifty-five and seventynine years of age. Urology, 1993;42:36-40. 15. Ku JH, Oh SJ. Comparison of voiding parameters in men and women with lower urinary tract symptoms. Neurourol Urodyn, 2006;25:13-8.

16. Kim YH, Goodman C, Omessi E, Rivera V, Kattan MV, Boone TB. The correlation of urodynamic findings with cranial magnetic resonance imaging findings in multiple sclerosis. J Urol, 1998;159:972-6.

17. Badia X, Garcia-Losa M, Dal-Re R. Tenlanguage translation and harmonization of the International Prostate Symptom Score: developing a methodology for multinational clinical trials. Eur Urol, 1997;31:129-40. 18. Abrams P, Klevmark B. Frequency volume charts: an indispensable part of lower urinary tract assessment. Scand J Urol Nephrol Suppl, 1996;179:47-53.

19. Haylen BT, Ashby D, Sutherst JR, Frazer MI, West CR. Maximum and average urine flow rates in normal male and female populations-the Liverpool nomograms. $\mathrm{Br}$ J Urol, 1989;64:30-8.

20. Ehrenberg A, Ehnfors M. The accuracy of patient records in Swedish nursing homes: congruence of record content and nurses s and patients> descriptions. Scand J Caring Sci, 2001;15:303-10.

21. Steindal SA, Sørbye LW, Bredal IS, Lerdal A. Agreement in documentation of symptoms, clinical signs, and treatment at the end of life: a comparison of data retrieved from nurse interviews and electronic patient records using the Resident Assessment Instrument for Palliative Care. J Clin Nurs, 2012;21:1416-24.

22. Koch T, Kelly S. Identifying strategies for managing urinary incontinence with women who have multiple sclerosis. J Clin Nurs, 1999:8:550-9.

23. Lode K, Bru E, Klevan G, Myhr KM, Nyland H, Larsen JP. Coping with multiple sclerosis: a 5-year follow-up study. keland universitetssykehus, som har bidratt til at studien lot seg giennomføre, og til min gode kollega sykepleier og uroterapeut, master i helsefag, og PhD student Jannicke Mohn ved urologisk poliklinikk, Haukeland universitetssykehus for hjelp ved innsamling av data.

Acta Neurol Scand, 2010:122:336-42. 24. Del Popolo G, Panariello G, Del Corso F, De Scisciolo G, Lombardi G. Diagnosis and therapy for neurogenic bladder dysfunctions in multiple sclerosis patients. Neurol Sci, 2008;29:S352-5.

25. van Haarst EP, Heldeweg EA, Newling DW, Schlatman TJ. The 24-h frequencyvolume chart in adults reporting no voiding complaints: defining reference values and analysing variables. BJU Int, 2004:93:125761.

26. Abrams P, Andersson KE, Birder L, Brubaker L, Cardozo L, et al. Fourth International Consultation on Incontinence Recommendations of the International Scientific Committee: Evaluation and treatment of urinary incontinence, pelvic organ prolapse, and fecal incontinence. Neurourol Urodyn, 2010;29:213-40.

27. Stöhrer $M$, Blok $B$, castro-Diaz $D$, Chartier-Kastler E, Del Popolo G, Kramer G, Pannek J, Radziszewski P, Wyndaele JJ. EAU guidelines on neurogenic lower urinary tract dysfunction. Eur Urol, 2009:56:81-8

28. Christ KF, Kornhuber HH. Treatment of neurogenic bladder dysfunction in multiple sclerosis by ultrasound-controlled bladder training. Arch Psychiatr Nervenkr, 1980:228:191-5.

29. Yap TL, Brown C, Cromwell DA, van der meulen J, Emberton M. The impact of self-management of lower urinary tract symptoms on frequency-volume chart measures. BJU Int, 2009;104:1104-8.

30 . Wyndaele JJ. Normality in urodynamics studied in healthy adults. J Urol, 1999: 161:899-902.

31. Khan F, Pallant JF, Shea TL, Whishaw M. Multiple sclerosis: prevalence and factors impacting bladder and bowel function in an Australian community cohort. Disabil Rehabil, 2009;31:1567-76

32. Bemelmans BL, Hommes OR, Van Kerrebroeck PE, Lemmens WA, Doesburg WH, Debruyne FM. Evidence for early lower urinary tract dysfunction in clinically silent multiple sclerosis. J Urol, 1991;145:1219-24

Les kommentaren på side 177 》 